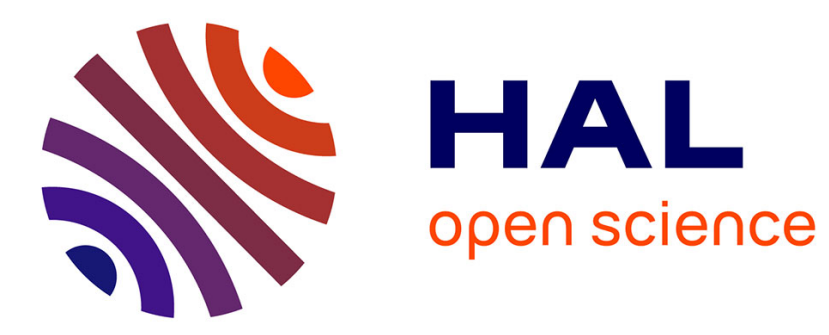

\title{
Nonprofit Roles in For-profit Firms: The Institutionalization of Corporate Philanthropy in France
}

\author{
Arthur Gautier, Anne-Claire Pache, Imran Chowdhury
}

\section{To cite this version:}

Arthur Gautier, Anne-Claire Pache, Imran Chowdhury. Nonprofit Roles in For-profit Firms: The Institutionalization of Corporate Philanthropy in France. 2013. hal-00914824

\section{HAL Id: hal-00914824 \\ https://essec.hal.science/hal-00914824}

Preprint submitted on 6 Dec 2013

HAL is a multi-disciplinary open access archive for the deposit and dissemination of scientific research documents, whether they are published or not. The documents may come from teaching and research institutions in France or abroad, or from public or private research centers.
L'archive ouverte pluridisciplinaire HAL, est destinée au dépôt et à la diffusion de documents scientifiques de niveau recherche, publiés ou non, émanant des établissements d'enseignement et de recherche français ou étrangers, des laboratoires publics ou privés. 


\title{
Nonprofit Roles in For-profit Firms: The Institutionalization of Corporate Philanthropy in France
}

\author{
Research Center \\ ESSEC Working Paper 1319
}

2013

\author{
Arthur Gautier \\ Anne-Claire Pache \\ Imran Chowdhury
}




\title{
Nonprofit roles in for-profit firms:
}

The institutionalization of corporate philanthropy in France

\author{
Arthur Gautier \\ ESSEC Business School \\ gautierart@essec.edu \\ Anne-Claire Pache \\ ESSEC Business School \\ pache@essec.edu \\ Imran Chowdhury \\ Pace University - Lubin School of Business \\ ichowdhury@pace.edu
}




\title{
Nonprofit roles in for-profit firms:
}

\section{The institutionalization of corporate philanthropy in France}

\begin{abstract}
In this research project we aim to understand the role of institutional entrepreneurship across multiple levels - field, organization, and micro levels - in the institutionalization of a new professional role within organizations. Specifically, we study the rise of the "corporate philanthropy manager," a position inspired by nonprofit values and goals which developed within large French corporations during the period 1979 to 2011. The process of creating, maintaining and legitimizing this new role - philanthropy as a new business function - is the central focus of our study, and we explore how elements of the nonprofit and for-profit worlds came together in this new role, as well as the role of various actors across multiple levels in influencing this combination.
\end{abstract}

Keywords: corporate philanthropy, professions, institutional change, institutional entrepreneurship, institutional work 
In recent decades, the philanthropic sector has undergone significant changes, leading to a blurring of the distinctions between nonprofit and for-profit organizations(Dees \& Anderson, 2003). Such sector bending arguably goes both ways. While "business-like" values and goals have permeated the nonprofit world through the adoption of commercial activities and managerial tools (Hwang \& Powell, 2009), corporations have borrowed several principles generally associated with nonprofits. As illustrated by the remarkable rise of the "corporate social responsibility" agenda (Porter \& Kramer, 2006), it is now common among for-profit organizations to tie social and environmental progress with economic performance in their business models. Organizational scholars have so far prioritized the former phenomenon (nonprofits borrowing from businesses) whereas the latter (businesses borrowing from nonprofits) remains largely under-scrutinized (Hwang \& Powell, 2009).

Often considered as the discretionary and voluntary capstone of the "pyramid of corporate social responsibility" (Carroll, 1991), the phenomenon of corporate philanthropy encapsulates this blurring of boundaries. Many corporations indeed make charitable monetary donations to address societal needs in various areas, from social welfare to education and the arts. A common view is that when company executives engage in corporate philanthropy, they willingly sacrifice short-term profits in favor of longer-term objectives, driven by a variety of motivations beyond pure altruism and self-interest (Fry, Keim, \& Meiners, 1982; Useem, 1988). While there is substantial literature assessing the benefits of corporate philanthropy on firm financial performance (Godfrey, 2005; Logsdon, Reiner, \& Burke, 1990; Porter \& Kramer, 2002), we are nevertheless left to wonder how the values and goals of philanthropy, associated with the nonprofit world, came to be embodied inside for-profit firms.

A promising yet understudied aspect of this question is the development of a new professional role within for-profit organizations: corporate philanthropy managers.Since 
professions are "both key mechanisms for, and primary targets of institutional change" (Muzio, Brock, \& Suddaby, 2010), exploring how these a priori illegitimate philanthropy functions emerged in corporations is an important first step to understand this redefinition of corporate boundaries. More specifically, we are interested in the institutionalization process of thesenew professional roles within organizations.

To explore this question, we build upon recent developments in the organization theory literature. A first series of papers focuses on the origins of new professional groups. Montgomery and Oliver (2007), for instance, show that whereas physician executives in the USA are "a hybridization of two professional groups", the legal profession in pre-state Israel emerged from "a segmentation within a well institutionalized professional group". A variant was studied by Rao, Monin and Durand (2003), who attributed the rise of nouvelle cuisine in France to an "identity movement" among elite players, led by a group of activist chefs promoting a new theorization of their profession. These studies highlight the fact that "new" professional roles often consist of rearrangements of existing ones, driven by "precipitating jolts" which destabilize established practice (Greenwood, Suddaby, \& Hinings, 2002) or by shifting institutional logics (Thornton \& Ocasio, 1999).

A second stream of research identifies the specific agents responsible for the institutionalization of novel professional roles, and draws heavily from research on institutional entrepreneurship (Battilana, Leca, \& Boxenbaum, 2009; Hardy \& Maguire, 2008). Scholars have so far used this agency approach to study emerging professional fields (Maguire, Hardy, \& Lawrence, 2004) or new professional role identities of established professions (Goodrick \& Reay, 2011). We are interested in extending this work to embrace a multi-level approach to institutional entrepreneurship with respect to the development of a new professional role. Thus far scholars have looked at various change agents at multiple levels, including individuals (Battilana, 2006), 
organizations and professional associations (Greenwood et al., 2002), social movements (Rao, Morrill, \& Zald, 2000) and regulatory agencies (Luoma \& Goodstein, 1999). To date, however, a multi-level approach to institutional entrepreneurship has been missing in the organizational theory literature (Battilana et al., 2009; Hardy \& Maguire, 2008).

Building upon these two streams of research, our aim is to understand the process through which a new professional role inspired by nonprofit values and goals emerged within for-profit corporations. Specifically, we study the rise of the "corporate philanthropy manager" position in large French corporations from 1979 to 2011. Thus, the process of creating, maintaining and legitimizing this new role - philanthropy as a new business function - is the central focus of the present research. In an attempt to account for the distributed view of agency in institutional processes (Battilana et al., 2009), we will explore, in particular, the role played by various actors at multiple levels in this process.

This article makes several contributions to the study of institutional entrepreneurship as well as institutional theory more broadly. First, it contributes to refining our understanding of the process of institutional entrepreneurship, by highlighting the diversity of actors playing different roles, at different levels to make institutional change happen. Second, it recognizes the duality of this entrepreneurial process, involving both individual and collective initiatives. As such, it contributes more broadly to enrich our understanding of institutional processes, by highlighting the interactions between the micro-level actions and macro-level processes.

\section{THEORETICAL BACKGROUND}

Neoinstitutional theorists began to address the issue of human and organizational agency when they started to tackle the phenomenon of institutional change, highlighting the role that actors play in institutional change (Dacin, Goodstein, \& Scott, 2002; Leblebici, Salancik, Copay, \& King, 1991; Rao et al., 2003) But because of the lack of explicit assumptions about human and 
organizational agency, neoinstitutional theory faced a theoretical paradox: "How can organizations or individuals innovate, if their beliefs and actions are all determined by the very institutional environment they wish to change?" (Holm, 1995). One way researchers have sought to overcome this "paradox of embedded agency" is to make the assumption that some actors are "institutional entrepreneurs" who have both an interest in and the social skills to destabilize the status quo (DiMaggio, 1988). A recent and growing stream of literature has started to explore the phenomenon of institutional entrepreneurship, focusing on three major issues: (1) Who are institutional entrepreneurs? (2) Where are they located in the social structure?; and (3) What is the process through which they generate institutional change?

Since DiMaggio's seminal paper (1988), a number of other scholars have attempted to refine this definition (Battilana et al., 2009; Colomy, 1998; Garud, Hardy, \& Maguire, 2007), but most converge around the notion that institutional entrepreneurs are actors who leverage their stock of resources to create changes in the existing institutional order or to create new institutions altogether. Importantly, while early studies focused on the interventions of single actors, more recent work emphasizes the collective dimension of institutional entrepreneurship (Lounsbury \& Crumley, 2007; Rao et al., 2000), suggesting that institutional entrepreneurship might be a collective phenomenon that involves different actors with access to various kinds and levels of resources who act in either a coordinated or uncoordinated way (Battilana et al., 2009)

While DiMaggio's original conceptualization recognized that these various institutional entrepreneurs could operate at multiple levels - organizational fields, organizations, groups, and individuals - most studies on the topic have to date focused primarily on the field and organizational levels of analysis (D'Aunno, Succi, \& Alexander, 2000; Dacin et al., 2002; Greenwood et al., 2002; Leblebici et al., 1991). Recently, however, there has been a surge of interest on the micro-foundations of institutional change (Powell \& Colyvas, 2008; Rao et al., 
2000). At the individual level, Battilana (2006) looked at the role of individual social positions in enabling change at the institutional and organizational levels. She found that certain positions within both the organization and the organizational field are more advantageous for undertaking institutional changes than others. Relatedly, Maguire and colleagues (2004), examined how certain individuals were positioned to act as institutional entrepreneurs because of their role as "bridges" between different groups of stakeholders. Others have looked at such factors as the role of entrepreneurship, or a simple profit motive on the part of agents, as a driver for individuals who introduce changes to the existing order which go beyond the economic realm to affect fundamental organizing principles and structure (Mutch, 2007). Overall, it is now widely recognized that institutional entrepreneurship is a phenomenon which is likely to be collective and which operates at multiple levels. What is however still missing in this picture is how interventions from various actors at these different levels interact to trigger and institutionalize change. The purpose of our paper is to address this gap.

Beyond the definitional issues associated with institutional entrepreneurship and the levels at which it has been studied, research on institutional entrepreneurship has explored the processes through which institutional entrepreneurship initiate and carry out changes to the existing institutional order. Various important types of interventions have been identified as key to this process of change. Tracey and colleagues (2011), for instance, identified six distinct processes of institutional work which enabled the institutionalization of social enterprises: framing the problem, counterfactual thinking, building the organizational template, theorizing the organizational template, connecting with a macro-level discourse, and aligning with highly legitimate actors. Maguire and colleagues (2004) emphasized two distinct yet related steps in the institutional change process: theorizing the change - which was done through the assembling of arguments that translate the interests of diverse stakeholders, as well as through the development 
of stable coalitions of diverse stakeholders through political tactic - as well asinstitutionalizing the change - in particular through attaching new practices to preexisting routines and by aligning them with the values of diverse stakeholders. More broadly, building upon process models of change (Lewin, 1947) as well as upon the work done by Battilana and colleagues (2009), we identified three main activities required to make institutional change possible: theorizing the change, which encompasses the activities undertaken to make the case for change, mobilizing for change, which includes the activities undertaken to gain others' support for and acceptance of new routines, and institutionalizing the change, which consists of activities undertaken to embed the change in well established structures and practices.

Surprisingly, the stream of literature exploring the profiles of institutional entrepreneurs and the one exploring the process through which change is institutionalized have so been poorly interconnected. While we now have fairly comprehensive understanding of who is likely to introduce institutional change as well as what actions this institutional change may entail, it is not clear what actors play what role in the overall process of change. To address this gap, we explore, in this paper the following research question: What role do different actors at different levels play in a process of institutional change? Specifically, we focus on the activities of actors at the field, organizational and micro level and how these interacted to produce change, namely the introduction of a new professional role within French companies. Importantly, analyzing in depth this process of institutionalization over a thirty years period, we were able to take time into account, and explore whether and how the activities conducted by these different actors at different levels evolved at different stages in the institutional change process.

\section{METHODS}

We use a qualitative inductive research design to understand the process through which corporate philanthropy became institutionalized in France over the last three decades (Miles 
\&Huberman, 1994). This methodology is well-suited to examining complex social phenomena as it allows us to develop a holistic understanding of real life events (Yin, 2003) and to elucidate the dynamic processes involving multiple causal chains (Pettigrew, 1992). Importantly, this design allows researchers to examine phenomena at multiple levels of analysis.

\section{Research Context}

There were several reasons why we chose to study corporate philanthropy in France. First, from our initial review of the field, it was clear that in the late $20^{\text {th }}$ century, corporate giving went through a period of significant development and change in France. We also noticed that in addition to the impact of several key individuals on changing established practices in this area, the efforts of a few key organizations also played a significant role in these change processes. Thus, this setting seemed promising for a multi-level exploration of institutional change processes. Second, the availability to our research team of extensive proprietary documentary data related to the institutionalization of corporate philanthropy, general and specialized press articles in the French language covering these issues, and access to several of the key players involved in the field of corporate philanthropy in France for personal interviews, meant that our historical study could draw from numerous sources of evidence.

\section{Data Collection}

Our research endeavor entailed assessing the degree to which the corporate philanthropy manager profession has been institutionalized in the French context over time as well as exploring the process through which this institutionalization occurred. To do so, we relied on a combination of historical evidence and information collected through interviews to track key events, legislative action, and changes in the broad field of corporate philanthropy in France during the thirty-two-year period from 1979 to 2011. 
The study uses two primary data sources: (1) archival data and documents that we used to track the historical evolution of the corporate philanthropy field in France as well as to assess the degree of institutionalization of corporate philanthropy professional roles in French corporations; and (2) in-depth, semi-structured interviews with key players involved in the development of corporate philanthropy in France that we conducted in order to explore the process through which this institutionalization occurred. This combination of documentary evidence and in-depth interviews allowed us to achieve a deep understanding of the process through which the new profession emerged, while keeping track of the significant events in the French and broader global context which influenced the development of this profession.

Data was collected in two phases. The first step of data collection, initiated in December 2011 involved the construction of a comprehensive database summarizing the information contained in the Repertoire of Corporate Philanthropy, a professional directory published every other year since 1981 by ADMICAL, the leading professional association of corporate philanthropy in France. This directory offers all companies engaged in corporate philanthropy in France - from SMEs to multinationals - to publicize information about 1) their corporate philanthropy activities, 2) the contact persons (up to three) managing these activities 3 ) the entity through which corporate philanthropy is managed (corporate foundation or a specific functional department). As we built this database, we coded, for each issue, all the information contained in the directory including company name, industry, corporate philanthropy entity, titles of officers as well as domains of intervention.

The second phase of data collection was initiated in January 2012. Its aim was to build a rich account of the process that led to the institutionalization of corporate philanthropy in France. To do so, we interviewed two categories of actors: 1) corporate philanthropy officers within large French companies and 2) corporate philanthropy experts who participated to the field's 
development. We carefully selected our sample of interviewees in order to include professionals with either a long experience in the field or a particular authority on the subject. The initial list of 21 actors with the aforementioned characteristic was composed by your ADMICAL informants. Using a snowball sampling strategy, we expanded our sample to 38 actors, with an equal representation of corporate philanthropy officers and experts.

\section{Data Analysis}

The data analysis comprised four main stages. First, we analyzed the data from our directory database in order to identify the degree to which corporate philanthropy professional roles were formally introduced in companies. We focused on companies listed on the CAC 40, a stock market index tracking the performance of France's 40 largest companies by market capitalization. For each of these entries, we coded the functions of the (up to three) contact person listed in the ADMICAL directory as in charge of the philanthropic activities. We coded as "formal corporate philanthropy positions" all the operational roles which explicitly contained "philanthropy" in their title; or which were formally attached to the corporate foundation. The other positions, which we coded as "non formalcorporate philanthropy positions", included top executive roles, communications managers, HR managers, or marketing managers. We tracked the adoption of formal roles between 1984 (the earliest date for which we can find relevant data) to the present and compared it with the number of CAC40 companies more broadly engaged in philanthropy. These patterns are represented on Figure 1, which highlights the progressive institutionalization of corporate philanthropy professional roles in France's largest companies.

Insert Figure 1 about here

Second, we developed a narrative account that chronicled the rise of the field of corporate philanthropy in France. We built upon our 38 interviews and a variety of archival data including press articles, ADMICAL newsletters and memos, doctoral theses. Going back and forth between 
interviews and archival data, we identified three main phases in the history of the field: the emergence phase (1979-1986), the growth phase (1986-2003) and the normalization phase (20032011). These periods correspond to the major phases through which the field evolved, from almost nonexistent to fairly institutionalized. We spotted, for each phase, the major events as well as their outcomes. Table 1 provides a chronology of this evolution.

Insert Table 1 about here

Third, we directly addressed our main research question: who did what, and when? We based this work on a qualitative analysis of the 38 interviews with corporate philanthropy officers and experts. More precisely, we devised a coding framework which enabled us to rigorously code each interview with the same method. In order to streamline this analysis, we used the qualitative data analysis software ATLAS.ti. During the coding process, we realized that multiple actors at various levels played important yet different roles in this process. We classified them across three broad levels of agency: field level, organization level, and micro level. For each activity, we analyzed the contributions to the institutionalization process. In particular, we traced back these interventions to preexistent models of institutional change, in order to understand the respective role these actors played in the change process. We further triangulated this analysis made on the basis of our interview data with archival data, in order to confirm, infirm or refine our analysis.

Fourth, we had the opportunity to present this framework and some early findings to the corporate philanthropy community, at an ADMICAL meeting with about 30 officers from large French firms. This interaction overall confirmed the relevance of our framework but also helped us refine it. Throughout the entire data analysis, we also exchanged ideas with ADMICAL executives and managers to make sure our findings were consistent with their knowledge of the field. 


\section{CORPORATE PHILANTHROPY IN FRANCE}

There is an overall agreement that the birth of modern corporate philanthropy in France can be traced back to the beginning of the 1980s(Debiesse, 2007; Seghers, 2007), when a combination of factors coalesced to introduce, within corporations, the idea that they could legitimately contribute to the common good, a practice which had so far remained the prerogative of the Church, the Kings or the State. Prior to 1979, corporate philanthropy efforts in France were scattered and mostly driven by CEOs' religious beliefs or by their desire to enhance their employees' condition in order to enhance their productivity and loyalty. These initiatives were marginal, hidden, unstructured and under-theorized. When discovered, by the press or the greater public, they were perceived as illegitimate and criticized as being hypocritical and paternalistic.

\section{The Emergence of Corporate Philanthropy (1979 - 1986)}

Referred to by one of our informants as "the times of installation", this period saw the emergence of a new practice in the French corporate world. In 1979, 3 young business school graduates, exposed to corporate philanthropy through a study trip in the US, decided to create ADMICAL (Association for the Development of Corporate Philanthropy) to introduce such practices in France. In 1980, looking for the endorsement of a visible and credible ambassador, they invited Jacques Rigaud to join as Chair of the Board. Rigaud was a senior civil servant, who had just stepped down from a position as chief of staff in the Ministry for Arts and Culture to become CEO of RTL, one of France's major media group. Rigaud had a passion for arts and culture and had himself envisioned how corporate philanthropy could contribute to their development. He recalls:

"I accepted [their invitation to join ADMICAL as Chair] because it really matched my plan. I had just become a corporate leader. I wanted to keep commitments with the cultural sector, and there came this new idea, corporate philanthropy. I was 
legitimate for that role for two reasons: I was a corporate leader myself, and I was deeply committed to the world of culture. Yet corporate philanthropy was totally unknown at the time, and the business leaders were convinced that the arts were the State's business."

The French political context at the time certainly had an influence over the emergence of corporate philanthropy. In 1981, for the first time since the Second World War, the left won the presidential election. François Mitterrand formed a socialist government and many business executives feared a backlash against private enterprises. Indeed, the first few years featured radical measures such as nationalization of several banks and industrial champions. Corporations were faced with a hostile environment and had to prove they were a positive force in French society, beyond making profits. Meanwhile, the Ministry of culture saw a twofold increase of its budget, as the socialist government intended to craft a very ambitious cultural policy. New public institutions such as the Opera de Parisor the Orsay Museum, as well as high-profile exhibitions, required additional funding. Some companies envisioned financing cultural projects as an excellent opportunity to prove their good behavior in these difficult times. While strong skepticism endured, pragmatic leaders of artistic and cultural organizations welcomed the addition funding from corporations. Few would have bet it would work out, in a country where the State was considered as the sole guarantor of general interest.

Under the leadership of Rigaud, ADMICAL organized in 1980 its first convention as well as the first "Corporate Philanthropy Awards", which rewarded with a symbolic prize, the best corporate philanthropy initiatives. Although there were very few of them at the time, this first event allowed ADMICAL to gain visibility and attract both curious journalists and intrigued corporate leaders. These events, subsequently organized every other year, became the hallmark of ADMICAL, alongside with its Corporate Philanthropy directory. Rigaud subsequently spent a 
considerable amount of time meeting with the press and CEOs, to explain them ADMICAL's view of corporate philanthropy, conceived as an opportunity for corporations to contribute to the common good, while strengthening their values, developing their capacity to innovate and building fruitful ties to the community around them. At the times, corporate philanthropy was essentially conceived in support for the arts.

In the early eighties, the first "modern" corporate philanthropy initiatives emerged. Interestingly, they first appeared in the French subsidiaries of major American corporations (IBM and HP), which had corporate philanthropy "in their DNA", then in large French public or cooperative companies, more used to take charge of the collective interest. They were initiated by CEOs, who liked the idea, yet immediately entrusted trustworthy staff, often experienced communications managers, with the responsibility to make these projects happen, in addition to their other responsibilities.

In 1986, Claude Bébéar, then President of AXA, France's largest insurance group and a thought leader in the business sector, pioneer of corporate philanthropy with AXA, created IMS (the Institute for Solidarity-focused Corporate Philanthropy) in order to increase the scope of corporate philanthropic activities by focusing on socially-oriented corporate philanthropic activities. Rigaud was rather hostile to this initiative and Bébéar was willing to demonstrate leadership in this field through the mobilization of his CEO friends. While ADMICAL had positioned itself as an advocate for corporate philanthropy and a representative membership organization providing members with networking opportunities, IMS positioned itself as a more hands-on actor, providing corporations interested in philanthropy with research and consulting services.

Taken together, these evolutions led to the emergence, in major companies, of the first corporate philanthropy positions. Some of the communication or HR managers who had initially 
been mobilized on philanthropicprojects on a part-time basis became fully in charge of corporate philanthropy activities. Usually directly reporting to the CEO, these officers were in charge of translating corporate philanthropy ambitions into practices within their companies. Yet they had little guidelines, tools, internal support or external benchmarks to rely on. They invented their new job while engaging in philanthropic relationships, mainly with major cultural institutions.

\section{The Growth of Corporate Philanthropy(1986 - 2003)}

Although Rigaud had voluntarily kept ADMICAL at a distance from public institutions, to maintain its independence as well as its legitimacy within the corporate world, he used his network at the highest level to influence legislation in favor of corporate philanthropy. In 1987, a first law was passed which legally defined the practice of corporate philanthropy and recognized it as a legitimate corporate activity. Although the fiscal advantages that it offered were minor, this first law constituted an important first step towards the institutionalization of these practices. It was followed, in 1990, by a second law; which instituted an official legal status for "corporate foundations". Until then, pioneering corporations had struggled to create the right vehicle for their philanthropic initiatives. The creation of an official legal status for corporate foundations thus removed an important obstacle to the engagement of companies in corporate philanthropy by providing them with a simple, ready-to-use vehicle to conduct their philanthropic activities. As corporations started to create these foundations, the number of corporate philanthropy managers progressively increased, since these autonomous entities required permanent staff to operate. With these two laws, corporate philanthropy gained visibility and legitimacy. In both cases, Rigaud and ADMICAL were instrumental in outlining the laws' content and lobbying the government for passing them.

In the early 90 s, a new societal trend gained momentum in the West: the idea that corporations ought to do more than just being profitable and providing jobs. On the one hand, an 
international consciousness about the environment reached an all-time high. Embodied by the Rio summit of 1992, this movement built upon the concept of "sustainable development" defined by the Brundtland Commission in the mid-80s. Environmental NGOs such as Greenpeace and Friends of the Earth increased the pressure on corporations to curb the environmental harm done by their activities. On the other hand, the concept of "corporate social responsibility", which was debated among business and scholarly communities since the 70 s, also became very prominent during the $90 \mathrm{~s}$. The main idea behind the concept was that corporations ought to take into account all the "stakeholders" concerned with their activities, not merely stockholders or customers. Both the "sustainable development" and "corporate social responsibility" concepts gradually became mainstream in business circles during this period.

The idea that corporations may engage in philanthropy became more widely accepted and corporations started to experiment with new activities. First, responding to IMS calls to see corporations committed to improving the welfare of the society, they started to engage in projects targeted to address societal and environmental issues, in addition to projects supporting the arts. Corporations further experimented with the development of employee volunteering programs, complementing their financial support to not-for-profit organizations with free expertise provided by managers and staff members. These programs highlighted the internal benefits associated with philanthropy, in terms of staff cohesion and motivation, in addition to external benefits related to public relations and communication.

This second period was one of steady development, where more and more corporations engaged in a wide range of philanthropic activities without necessarily really knowing precisely what to do and how to do it. They were, however, more clear about why they were doing it. Importantly, in a centralized country like France, local corporate philanthropy groups emerged outside of the capital, enabling local corporate leaders to engage in philanthropy. 


\section{The Normalization of Corporate Philanthropy (2003-2011)}

This last phase started with a major milestone for the field: a new law providing the field with one of the most favorable fiscal conditions for philanthropic activities (of corporations, as well as individuals) in the world. That law granted corporations with the right to annually deduct $60 \%$ of their gift from corporate taxes (within the limit of $0,5 \%$ of turnover), under the conditions that those gifts would be allocated to nonprofit or public organizations serving the common good, rather than private interests. The law not only created fiscal incentives for corporations to engage in philanthropy, it further and more broadly legitimized, philanthropic practices in France. The transformation of the regulatory framework for corporate philanthropy was finalized by the passing, in 2007, of another law instituting "fonds de dotation" (endowment funds). This idea was to offer any individual or corporation interested in committing funds to serve the collective interest to create a very simple vehicle, with neither minimum level of endowment nor a priori controls over its social mission, yet with a full capacity to receive all types of funds. In less than 30 years, the field went from being one of the most archaic in terms of its infrastructures to one of the best equipped in the Western world.

Having discreetly yet efficiently lobbied for and contributed to the writing of the 2003 law, Jacques Rigaud was very satisfied to see it promulgated. Yet, in his mid seventies, having spent 25 years leading ADMICAL and championing corporate philanthropy in France, he felt like it was time for him to hand over leadership. In 2007, he stepped down as Chair of ADMICAL, and was replaced by one of ADMICAL's members, the head of corporate philanthropy for Orange (France Telecom).

In 2008-2009, as the financial crisis hit France, a few voices predicted that the degradation of the financial situation of French corporations would translate into drastic decreases in the budgets allocated to corporate philanthropy, suggesting that corporate 
philanthropy is a discretionary activity in good times, and one of the first budget items eliminated in bad times. The levels of philanthropic commitments by corporations in 2010 contradicted that view, highlighting a $20 \%$ decrease compared to 2008 , yet maintaining overall high levels of contributions at about 2 billion Euros ${ }^{1}$, a level twice as high as the amount distributed in 2005. The major impact of the crisis was that corporations shifted their support from artistic-cultural to social, educational, health and sports causes: whereas culture mobilized 39\% of the corporate philanthropy budget in 2008 , it only represented $19 \%$ of it in 2010 , with other causes gaining prevalence. Overall, the financial crisis demonstrated the resilience of these practices and their relative institutionalization in French society. Meanwhile, the "corporate social responsibility" agenda proved to be much more than a fad: corporate leaders quickly understood the new expectations upon their activities and some took social and environmental performance extremely seriously. One may argue that the financial crisis only furthered this movement.

Two initiatives, respectively by IMS and ADMICAL, further illustrate the evolution of the field towards normalization and standardization. In 2010, IMS produced the first study about the professional profile of corporate philanthropy managers, in an attempt to define their roles, their responsibilities as well as the main skills required. Mobilizing 12 corporate philanthropy managers to produce this material, IMS contributed, with this study, to set the standards of a role which had so far lacked a formal description. It was shared within the IMS network and made available broadly to all actors with an interest in the exercise of corporate philanthropy. These efforts were complemented by ADMICAL's initiative, in 2010, to develop "The Charter of Corporate Philanthropy", intended to define norms and encourage "best practices" for this activity. The Charter articulated what corporate philanthropy is, what it brings to corporations as well as what it brings to beneficiaries. It offered, in addition, actors to sign a commitment to

\footnotetext{
${ }^{1}$ ADMICAL 2010 Survey
} 
respect this charter and to publicize it. In 2011, the charter was signed by 164 large companies across France.

Over thirty years, the French society profoundly modified its attitude towards corporate philanthropy: "The major evolution of these last years is a real change of mentalities: it is today more illegitimate not to engage in corporate philanthropy than to engage in it. Especially when it comes to major companies, people do not wonder what they try to get redemption for, but rather why they do not care more about their environment," (Seghers, 2007: 45). This institutionalization of the idea and practice of philanthropy in French corporations translated into the institutionalization of the corporate philanthropy professional role in French corporations. While the position did not exist at all in French corporations before 1979, it became, over a 30 years period, a widely accepted function, alongside communication, marketing, or HR positions. This trend is illustrated by the progressive increase of the number of corporate philanthropy managers in CAC 40 corporations between 2003 and 2011 (see Figure 1). The sedimentation of this function in corporations came along with a formalization of its content. We now turn to the process that allowed this change to occur, highlighting the contribution of various actors in this process over time.

\section{FINDINGS}

What role did different actors at different levels play in the institutionalization of the practice of corporate philanthropy in France, and in the related introduction of corporate philanthropy functions in companies? In examining our data, we not only found that different actors played different roles in contributing to the three key change processes (theorizing, mobilizing resources and institutionalizing) but that these roles evolved over time. We further identified a very key role played at the micro-level by corporate philanthropy managers who played a hidden yet fundamental function of "muddling through" the practicalities of their role. 


\section{Theorizing Corporate Philanthropy: A Field and Organizational Level Role}

As highlighted in previous research, an important step in the institutionalization of corporate philanthropy in France consisted in theorizing the desired new institution (Greenwood et al., 2002; Strang \& Meyer, 1993), i.e. explaining what corporate philanthropy was about, and what consequences it could have for corporations, for beneficiaries as well as for society at large. The way in which theorization was conducted evolved over time as societal level as well as field level conditions changed.

Emergence phase.During this phase, ADMICAL and its co-founders were the driving force behind theorization. Their first contribution was to translate (Sahlin \& Wedlin, 2008) the American concept of Corporate Philanthropy to France. Whereas both the three young cofounders and Rigaud recognized that they were inspired by the US practices, they also made a conscious effort to adapt the concept to France, a country were the people had decided, since the French Revolution, to transfer responsibility for the common good to the State. First, they framed corporate philanthropy as "a modern management approach", as a "use of funds that would speak to the company's interests" or as a "corporation's signature", highlighting the embodiment, by corporate philanthropy, of the firms' values. Overall, their discourse was oriented towards corporate leaders, in an attempt to convince them that they had a role to play in funding the arts, beyond the State's prerogatives.

ADMICAL's leaders further played an important role in theorizing what corporate philanthropy was not. Their discourse was mainly directed to journalists, who were highly skeptical about the idea. Corporate philanthropy was framed as radically different from "sponsoring" or "advertising", (practices which imply, for the corporation, a measurable return to the investment made). It was neither a way for corporations to "redeem themselves" or to "spend shareholders' monies on the CEO's pet issues". They further argued that corporate 
philanthropy was not a strategy designed "to help the State compensate for a diminishing budget". The movement was to be understood as a sincere initiative from civil society. An important way through which ADMICAL took distance from the US practice of corporate philanthropy was by choosing the label "mécénatd'entreprise" (in English, corporate patronage), instead of "philanthropied'entreprise" (corporate philanthropy), to characterize the practice. The term "mécénat", referred to the support of writers, sculptors and musicians, a practice hence institutionalized by Caius Maecaenus, an advisor to Emperor August in ancient Rome. It allowed ADMICAL to avoid confusion with "philanthropie", considered as the charitable practice of giving without any expectation of return, a practice which would have been problematic for shareholders. This theorization, conducted at the field level by ADMICAL's co-founders and diffused mainly by Rigaud in corporate and media circles, allowed for the idea of corporate philanthropy to gain momentum.

Growth phase.During the growth phase, ADMICAL struggled to keepthe leadership in the theorization process. Rigaud further failed to perceive, that at the organization level, a theorization process had started to emerge. The first corporations engaged in corporate philanthropy had indeed started to reflect about their philanthropic practices and realized that they not only positively impacted their beneficiaries, but also impacted, in important ways, their staff members. As these members reported to be proud with these philanthropic activities and asked to be more involved, corporations started to reflect about the real impact that these activities could have. They then started to realize the potential impact that corporate philanthropy could have on internal cohesion and skills development, as well as on aspects of civil society other than the arts, where staff's competencies were not necessarily much needed. This new conceptualization of corporate philanthropy - as a tool to serve society's social needs, through the 
mobilization of corporate financial and human resources - emerged at the organizational level from corporate actors. Rigaud recalls:

"It is the corporate philanthropy managers, who were in contact with ADMICAL, who came to me saying: "It should not be all about culture". So I told them: "I am not able to deal with all human misery".",

Claude Bébéar, AXA's president, who had initiated very active employee volunteering policies within AXA, took leadership on this issue. As he realized that Rigaud was not willing to embrace this view and theorize it at the field level, he decided to create IMS, to promote this view outside of AXA.

Normalization phase.During the normalization phase, theorization, again, took place at the organizational and field level. At the organization level, corporations were introduced to the notion of corporate social responsibility in the late 90's. In 2001, a law instituted that all publicly listed corporations report, in their annual report, on their corporate social responsibility practices. More broadly, the idea that corporations had responsibilities vis-à-vis a wide range of stakeholders (including shareholders, employees, suppliers, local communities, the natural environment and NGOs) and that corporation could not ethically and strategically ignore that responsibility had gained a lot of momentum, leading to the rise, alongside corporate philanthropy managers, of Corporate Social Responsibility managers. Rigaud had a strong disdain for the idea that corporate philanthropy could be integrated into CSR policies. He believed that this would lead to the instrumentalization of corporate philanthropy to serve a company's interest, an evolution that would fundamentally question the tax breaks that corporations received in compensation for their philanthropic commitments. This made him reluctant to theorize about the potential synergies between corporate philanthropy and CSR, leaving organizations on the ground as well as medias cope on their own with this debate. 
At the organization level, corporations, which were practicing CSR on a daily basis, developed their own theories of how corporate philanthropy would fit in the broader firm's strategy. Two opposing views developed, with those in favor or creating as many synergies as possible between philanthropy and strategy, and those conceiving of corporate philanthropy as an activity outside of the scope of the business. In the former corporations, formal positions emerged combining corporate philanthropy and CSR responsibilities, while in the later, the positions remained clearly distinct.

In 2011, that theoretical debate was still vibrant in the corporate philanthropy field. ADMICAL was still strongly defending a position of a clear disconnection between the two, as promoted by its Charter, while other actors, such as IMS at the field level, or firms, at the organization level, strongly promoted a more synergetic approach. The very existence of this debate was clear evidence that the question of whether corporate philanthropy was a legitimate activity for French corporation has been resolved, in a positive way, and that the next question had become: how should corporate philanthropy be implemented. Table 2 presents an outline of the theorization activities.

Insert Table 2 about here

\section{Mobilizing Resources for Corporate Philanthropy: The Importance of Field Actors}

Interestingly, while the theorization process proceeded through iterative interactions between field level and organizational level actors, the resource mobilization part of the change process was mainly driven by actors at the field level.

Emergence phase. During this phase, mobilizing resources to introduce corporate philanthropy to France mainly involved convincing corporate leaders to adopt philanthropic practices. In the early years, this was mainly done through the personal contacts of Rigaud. His long career in the highest levels of administration as well as his position as RTL CEO had 
allowed him to develop close relationships with various CEOs or to have easily access to them. Rigaud recalls:

"A lot of this happened through personal contacts. As Haberer, the president of Paribas (one of France's leading bank) invited me for lunch, he told me: "I would like to organize a lunch with my executive team so that you can make them aware of corporate philanthropy. I believe that a corporation like Paribas should engage in philanthropy”. So I went, I put on my usual act. And this is how all of this started."

Paribas subsequently became one of the pioneers in the corporate philanthropy space. Rigaud further played an important role in mobilizing the media. His strategy to organize the first Corporate Philanthropy convention in 1980 as well as the corporate philanthropy Awards, was a deliberate attemptto mobilize corporate actors around the cause. His goal, with the convention, was to make people feel like the issue was already widely accepted, and, through the Awards, which rewarded the companies demonstrating leadership in corporate philanthropy, to appeal to companies eager for an easy recognition. His strategy overall worked, and these first events were such successes that they were subsequently, and until today, reproduced every other year.

During the early years, ADMICAL also devoted resources to gain acceptance from the beneficiaries of the corporate philanthropy. The cultural institutions - which were targeted as beneficiaries during that phase - did not have any prior experience working with corporations and its leaders were not particularly open to it. They viewed corporations as "temples of profit" where the arts had little to do. Rigaud's legitimacy in the cultural world played an important role in helping ADMICAL recruit cultural institutions. The first to participate in philanthropic relationships with corporations were the major cultural institutions (for example, the Louvre or 
Versailles) which were culturally more inclined to work with corporations, and which also had more appeal for the corporations interested in investing in the arts.

Finally, ADMICAL further initiated very early on networking activities among the few actors actually involved, on a day to day basis, in philanthropic activities, to help them make sense of their role within corporation as well as of their role outside of corporations, in relationship with their beneficiaries. Its newsletter, the repertoire that it published as well as the workshops that it organized contributed to this collective sense making process.

Growth phase. During the growth phase, ADMICAL continued that mobilization process through strengthening and structuring its networking activities among practitioners of corporate philanthropy. During that phase, ADMICAL confirmed its positioning as a resource center for practitioners rather than as a CEOs' club. While that second strategy could have been a feasible option given Rigaud's network, it was a deliberate choice by ADMICAL to contribute to the actual strengthening of the field on the ground, rather than push political agendas. When needed, the political agendas were pushed by Rigaud, but the majority of the work was done by bringing the new guard of corporate philanthropy managers together, getting them to share their successes, their failures, their doubts and their best practices. By providing concrete consulting services to companies, IMS pursued a different strategy, yet contributed in a similar way to the strengthening of the capacities of field actors.

Normalization phase. During the most recent phase, given the high level of acceptance of the corporate philanthropy both in the corporate world as well as more broadly in society, mobilization became a less central activity in the change process: the main stakeholders were now convinced of its appropriateness. ADMICAL continued its networking activities and continued organizing its Awards and its convention every other year, which had become, over 
time, France's landmark event for corporate philanthropy. The resource mobilization activities are presented in Table 3.

Insert Table 3 about here

\section{Institutionalizing Corporate Philanthropy: The Core Role Played by Micro-Level Actors}

An important finding of this study was that micro-level actors, i.e. the staff involved in corporate philanthropy activities, played a major role in the institutionalization part of the change process. While ADMICAL, Rigaud and other field actors played an important role to "sell the idea", these micro level actors were those who actually made it happen, produced evidence of its impact, and ultimately enabled its adoption as a legitimate corporate activity.

Emergence phase. During the emergence phase, micro-level actors were the only actors who played a substantial role in the institutionalizing the change. They literally made corporate philanthropy happen. While this contribution was not fully deliberate on their part - rather the outcome of the situation in which they were put by the CEOs who asked them to implement their corporate philanthropy projects - they nevertheless engaged in it with passion and energy. What characterized this emergence phase is that these actors were lost: they were asked to implement philanthropic initiatives, without being given any guidelines about why exactly do it and how to go about it. Importantly, it was very difficult for them to find support, inside or outside of the company. One of these pioneers recalls a discussion she had with a peer in an ADMICAL meeting in 1985:

"Frankly, I did not know what we were doing. As I saw this ESSO guy, I thought, "ESSO is a big company, so he should know". So I asked him: "What do you do?" He said: "I have no idea. I am here but I don't know why I was sent here [to the ADMICAL meeting]. I really don't understand what this all means for companies." 
It was a revelation to me. I thought: There is no framework. We are all floundering.

Rigaud perorates, but we all have to invent our own stories."

As close collaborators to the company's CEO, these pioneers had no other alternative but to experiment with philanthropic activities. Mainly recruited among communications managers (sometimes among HR managers), usually on the basis of their good knowledge of the company and its important members as well as on a prior trust relationship developed with the CEO, they had no specific expertise about arts and culture. They therefore started their journey through meetings with artists, through visits of exhibitions and other cultural institutions. Their goal was to understand what the need of these people were, and how the company could help. In early years, the approach was rather elitist: granting support to cultural activities was already risky in itself, so taking further risks through the patronage of alternative art was not an option.

These pioneers were isolated in the company, having no colleagues dealing with similar issues (or having dealt with similar issues in the past), being perceived as atypical organizational members, namely the only ones pursuing nonprofit goals. Also, at that time, there was hardly any professional model available outside the firm. Our interviewees from this period referred to themselves at as the time as "marginalized", "schizophrenics", "free electrons" and reported having been renamed by colleaguesas "artists" or "entertainers". Interestingly, what our analysis revealed, was that these first pioneers relied on two sources of legitimacy to operate and to legitimatize their activities. On the one hand, their close ties to the CEO allowed them to overlook the skepticism that their activities sometimes spurred internally. On the other hand, the close and very fruitful relationships that they developed with beneficiaries outside of the corporation, further contributed to legitimatize their role, and provide them with enough fuel to pursue their exploration. 
The relationships that these actors developed with beneficiaries not only enhanced their external and internal legitimacy. They further provided these actors with important references when it came to learn their jobs. One of these pioneers explains where she turned to learn about her new role:

"Those who inspired us were the professionals in the arts world. The directors of big theaters.People with whom we developed affinities, with whom we exchanged a lot, who thought that we were their peers. This helped a lot."

Overall, the contribution of micro-level actors was decisive during this phase because they engaged in the institutional work which allowed for actual corporate philanthropy practices to be legitimized, both internally and externally. Without their ability to "muddle through" (Lindblom, 1959) this new role and responsibility, corporate philanthropy could have remained talk or turned into a highly illegitimate activity.

Growth phase. During the growth phase, this role slightly evolved, as the number of peers increased and experience was gained by the pioneers. As their numbers increased, full time corporate philanthropy officers found comfort in the exchanges organized by ADMICAL. Building upon their early successes, corporate philanthropy officers gained confidence and started to interact more closely with other actors inside the corporation, with HR managers in the context of employee volunteering programs, or with communication services, in order to communicate about the initiatives that they supported. One interviewee recalls:

"At some point, we thought: enough with being so shy about what we do. We have done some amazing things. We are not being immodest about it (...). So that's enough now. We should let people know."

Their legitimacy within the organization increased as a result of these positive interactions. These actors nevertheless remained overall isolated from the main activity of the 
company and identity struggles were permanent. They were contributing to support artistic or social enterprises, yet they were neither artists nor social workers. They were working for their company's success, yet they spent revenues instead of generating them. They were close to the company's leadership, yet had no clear contribution to the company's strategy. To resolve these identity struggles as well as to facilitate recruitments, corporate philanthropy officers started to develop templates for their work: they started to work out job descriptions, which defined what their main activities were, as well as their key competencies. These initiatives were reinforced by the exchanges that they had with peers in the context of ADMICAL or IMS meetings. During the growth phase, corporate philanthropy actors played an important role in the institutionalization process through their working out of the fundamentals of their function.

Normalization phase.During the normalizing phase, micro-level actors further contributed to the institutionalization of their function. First, they did so through the deliberate introduction, in their own work, of impact assessment routines. They introduced these routines, targeted to measuring the outputs as well as the outcomes of their philanthropic support, to assessing the societal impact of each project as well as the aggregate impact of their philanthropic activities, partly under internal pressure to report on their activities. However, they also embraced these efforts as a means to legitimize their contributions, both internally and externally.

Second, as they learnt to cope, over time, with the identity struggles which had been theirs over the previous period, corporate philanthropy officers builttheir identities as nonprofit managers within a for-profit. Except for the first pioneers, who were about to retire as corporate philanthropy officers when we interviewed them, the younger corporate philanthropy officers that we interviewed recurrently reported that it was difficult for them to envision their future in the company, since no other position could provide them with the same richness and opportunities to contribute to the common good as their current job. What some of them thus envisioned, was to 
transfer, at some point to managerial positions in the nonprofit world. Table 4 represents the institutionalization of corporate philanthropy and officers.

Insert Table 4 about here

\section{DISCUSSION AND CONCLUSION}

Our research seeks to make several contributions to the literatures on institutional entrepreneurship, institutional work, and the micro-foundations of institutional theory. As noted by Battilana and colleagues (2009), the literature on institutional entrepreneurship has yet to develop a robust model of distributed agency, wherein the outcomes of the institutional change processes are the result of the efforts and actions of multiple actors at multiple levels. By working to understand how a new professional role inspired by nonprofit values and goals rose within for-profit corporations in France, we delve into the processes through which multiple actors worked to develop the emerging field of corporate philanthropy. To this end, we offer a multi-level account of institutional entrepreneurship processes.

We found that different actors played different roles in contributing to the processes of theorizing, mobilizing resources and institutionalizing change as identified in prior research, and that these differences can be segregated by level at which actors operated. In general, field-level institutional entrepreneurs contributed to the processes of theorization and resource mobilization, which are key in the beginning stages of the institutional change process. At this point, defining, adding legitimacy to, and developing a pool of support (political, financial and otherwise) for the change effort is most essential. Organization-level actors were also key in the theorization process after the initial conceptualization of corporate philanthropy. Insofar as corporations adopted philanthropic practices and realized that these practices positively impacted their beneficiaries and staff members, they were able to orient philanthropic activities away from arts- 
related concerns to those that better served their internal cohesion and skills development for their workers. Thus, a conception of corporate philanthropy as a tool to serve society's social needs was theorized very much at the organizational level. Individual-level actors played a significant role in the actual institutionalization of change efforts. Whereas theorization and resource mobilization created the conditions for change to occur, it is the actions of individual staff members involved in corporate philanthropy activitieswhich led to the solidification of these activities within French corporations. Often asked to implement philanthropic initiatives without being given much guidance about how to go about it, these managers in a sense created the reality of corporate philanthropy on-the-ground with their actions.

A second area of contribution is to the literature on institutional work (Lawrence, Suddaby, \& Leca, 2009). Specifically, we examined not only the actions of actors at multiple levels, but also the types of activities that these actors engaged in to bring about institutional change. For instance, in the theorization example referred to above, while field-level actors helped to initially define the field of corporate philanthropy and oriented its focus towards cultural activities, organization-level actors subsequently added corporate philanthropy activities which were socially oriented. In this instance the actions of actors at multiple levels was cumulative in first defining and then expanding the scope of corporate philanthropy, but unwittingly so. Field-level actors could not have predicted the actions of organization-level actors, and organizational-level actors adapted an emerging template to their own interests and values.

Our paper also contributes to the emerging literature on the micro-foundations of institutional theory (Powell \& Colyvas, 2008). As noted by Powell and Colyvas(2008), institutions are "sustained, altered, and extinguished as they are enacted by individuals in concrete social situations." In this study, we attend to the way in which individual participants in the institutional change process - i.e. micro-level institutional entrepreneurs - created the 
everyday practices that came to define the field of corporate philanthropy. They did this by crafting solutions to the broad-level guidance (or lack of guidance) coming from the field and organizational levels. Whereas the processes of theorization and resource mobilization created the conditions for the emergence of corporate philanthropy, actors at the field and organizational ideas had little idea about how their vision would be implemented through micro-routines and actions within companies. Micro-level actors within organizations, that is, corporate philanthropy managers, defined their own roles and "muddled through" the process of organizing and conducting their work.

Beyond these contributions to the literature, we believe our study has practical implications for the main actors of corporate philanthropy in France as well as throughout Europe and elsewhere. By understanding the historical conditions as well as institutional influences which led to the rise of a new profession, these actors may be better equipped to understand the future role of this profession across the business world and society. 


\section{REFERENCES}

Battilana, J. 2006. Agency and Institutions: The Enabling Role of Individuals' Social Position. Organization, 13(5): 653-676.

Battilana, J., Leca, B., \& Boxenbaum, E. 2009. How Actors Change Institutions: Towards a Theory of Institutional Entrepreneurship. Academy of Management Annals, 3: 65-107.

Carroll, A. B. 1991. The pyramid of corporate social responsibility: Toward the moral management of organizational stakeholders. Business Horizons, 34(4): 39-48.

Colomy, P. 1998. Neofunctionalism and neoinstitutionalism: Human agency and interest in institutional change. Sociological Forum, 13(2): 265-300.

D'Aunno, T. A., Succi, M., \& Alexander, J. A. 2000. The Role of Institutional and Market Forces in Divergent Organizational Change., Administrative Science Quarterly, Vol. 45: 679703: Administrative Science Quarterly.

Dacin, M. T., Goodstein, J. D., \& Scott, W. R. 2002. Institutional theory and institutional change: Introduction to the special research forum. Academy of Management Journal, 45: 45-57.

Debiesse, F. 2007. Le mécénat. Paris: Presses Universitaires de France.

Dees, J. G., \& Anderson, B. B., 40(4): 16-27. 2003. Sector-bending: Blurring lines between nonprofit and for-profit. Society, 40(4): 16-27.

DiMaggio, P. J. 1988. Interest and agency in institutional theory. In L. G. Zucker (Ed.), Institutional patterns and organizations: Culture and environments: 3-21. Cambridge, MA: Ballinger.

Fry, L. W., Keim, G. D., \& Meiners, R. E., 25(1): 94-106. 1982. Corporate Contributions: Altruistic or For-Profit? The Academy of Management Journal, 25(1): 94-106.

Garud, R., Hardy, C., \& Maguire, S. 2007. Institutional Entrepreneurship as Embedded Agency: An introduction to the Special Issue. Organziation Studies, 28(7): 957-969.

Godfrey, P. C. 2005. The Relationship between Corporate Philanthropy and Shareholder Wealth: A Risk Management Perspective. The Academy of Management Review, 30(4): 777-798.

Goodrick, E., \& Reay, T. 2011. Constellations of institutional logics: Changes in the professional work of pharmacists. Work \& Occupations, 38(3): 372-416.

Greenwood, R., Suddaby, R., \& Hinings, C. R. 2002. Theorizing change: The role of professional associations in the transformation of institutionalized fields. Academy of Management Journal, 45(1): 58-80.

Hardy, C., \& Maguire, S. 2008. Institutional entrepreneurship. In R. Greenwood, C. Oliver, R. Suddaby, \& K. Sahlin-Andersen (Eds.), Handbook of Organizational Institutionalism: 198-217. London, UK: Sage.

Holm, P. 1995. The dynamics of institutionalization: Transformation processes in Norwegian fisheries. Administrative Science Quarterly, 40: 398-422.

Hwang, H., \& Powell, W. W. 2009. The Rationalization of Charity: The Influences of Professionalism in the Nonprofit Sector. Administrative Science Quarterly, 54(2): 268298.

Lawrence, T. B., Suddaby, R., \& Leca, B. 2009. Introduction: Theorizing and studying institutional work. In T. B. Lawrence, R. Suddaby, \& B. Leca (Eds.), Institutional Work: 1-27. Cambridge: Cambridge University Press.

Leblebici, H., Salancik, G. R., Copay, A., \& King, T. 1991. Institutional change and the transformation of interorganizational fields: An organizational history of the U.S. radio broadcasting industry. Administrative Science Quarterly, 36(3): 333-363.

Lewin, K. 1947. Frontiers in group dynamics. Human Relations, 1(1): 5-41. 
Lindblom, C. E. 1959. The science of 'muddling through'. Public Administration Review, 19(2): 78-88.

Logsdon, J. M., Reiner, M., \& Burke, L., 19(2): 93 -109. 1990. Corporate Philanthropy: Strategic Responses to the Firm's Stakeholders. Nonprofit and Voluntary Sector Quarterly, 19(2).

Lounsbury, M., \& Crumley, E. T. 2007. New practice creation: An institutional perspective on innovation. Organization Studies (01708406), 28(7): 993-1012.

Luoma, P., \& Goodstein, J. 1999. Stakeholders and Corporate Boards: Institutional Influences on Board Composition and Structure. The Academy of Management Journal, 42(5): 553563.

Maguire, S., Hardy, C., \& Lawrence, T. B. 2004. Institutional Entrepreneurship in Emerging Fields: HIV/AIDS Treatment Advocacy in Canada. Academy of Management Journal, 47(5): 657-679.

Montgomery, K., \& Oliver, A. L. 2007. A Fresh Look at How Professions Take Shape: Dualdirected Networking Dynamics and Social Boundaries. Organization Studies, 28(5): 661687.

Mutch, A. 2007. Reflexivity and the institutional entrepreneur: A historical explanation. Organization Studies, 28(7): 1123-1140.

Muzio, D., Brock, D., \& Suddaby, R. 2010. Call for Papers: Professions and Institutional Change. Journal of Management Studies.

Pettigrew, A. M. 1992. The character and significance of strategy process research. Strategic Management Journal, 13(Winter special issue): 5-16.

Porter, M. E., \& Kramer, M. R. 2006. Strategy \& Society: The Link Between Competitive Advantage and Corporate Social Responsibility. Harvard Business Review, 84(12): 7892.

Porter, M. E., \& Kramer, M. R. 2002. The Competitive Advantage of Corporate Philanthropy. Harvard Business Review, 80(12): 56-69.

Powell, W. W., \& Colyvas, J. A. 2008. Microfoundations of Institutional Theory. In R. Greenwood, C. Oliver, R. Suddaby, \& K. Sahlin-Andresson (Eds.), The Sage Handbook of Organizational Institutionalism: 840. London: Sage.

Rao, H., Monin, P., \& Durand, R. 2003. Institutional change in Toque Ville: Nouvelle Cuisine as in identity movement in French gastronomy. American Journal of Sociology, 108(4): 795-843.

Rao, H., Morrill, C., \& Zald, M. N. 2000. Power plays: How social movements and collective action create new orgnanizational forms. Research in Organizational Behavior, 22: 239282.

Sahlin, K., \& Wedlin, L. 2008. Circulating Ideas: Imitation, Translation and Editing. In R. Greenwood, C. Oliver, K. Sahlin, \& R. Suddaby (Eds.), The Sage Handbook of Organizational Institutionalism. London: Sage.

Seghers, V. 2007. Ce qui motive les entreprises mécènes. Paris: Editions Autrement.

Strang, D., \& Meyer, J. 1993. Institutional conditions for diffusion. Theory and Society, 22: 487511.

Thornton, P. H., \& Ocasio, W. 1999. Institutional Logics and the Historical Contingency of Power in Organizations: Executive Succession in the Higher Education Publishing Industry, 1958-1990., American Journal of Sociology, Vol. 105: 801-844: University of Chicago Press.

Useem, M. 1988. Market and institutional factors in corporate contributions. California Management Review, 30(2): 77-88.

Yin, R. K. 2003. Case study research: Design and methods. Thousand Oaks, MA: Sage. 


\section{TABLE 1}

The institutionalization of corporate philanthropy in France (1979 - 2011)

\begin{tabular}{|c|c|c|c|}
\hline $\begin{array}{c}\text { Phase 0 } \\
\text { (Before 1979) }\end{array}$ & $\begin{array}{c}\text { Emergence Phase } \\
(1979-1986)\end{array}$ & $\begin{array}{r}\text { Growth Phase } \\
(1987-2003)\end{array}$ & $\begin{array}{c}\text { Normalization Phase } \\
\text { (2003- 2011) }\end{array}$ \\
\hline $\begin{array}{l}\text { Since the lateXIXth } \\
\text { century: Scattered } \\
\text { initiatives of corporate } \\
\text { philanthropy are } \\
\text { developed across France } \\
\text { by paternalistic CEOs }\end{array}$ & $\begin{array}{l}\text { 1979: ADMICAL (Association } \\
\text { for the Development of Corporate } \\
\text { Philanthropy) is created by three } \\
\text { business schools graduates to } \\
\text { promote corporate philanthropy in } \\
\text { France. } \\
\text { 1980: Jacques Rigaud joins } \\
\text { ADMICAL as chair of the board. } \\
\text { 1980: ADMICAL organizes its } \\
\text { first convention in } 1980 \text { as well as } \\
\text { its first Awards. } \\
\text { Early 80s: philanthropic } \\
\text { practices, with a focus on culture, } \\
\text { emerge in pioneer organizations, } \\
\text { initiated by CEOs and led } \\
\text { operationally by communication } \\
\text { managers. } \\
\text { 1986: Creation of IMS, the } \\
\text { "Institute of Corporate } \\
\text { Philanthropy for Solidarity" in } \\
\text { 1986. } \\
\text { Mid 80s: Emergence of first } \\
\text { corporate } \\
\text { philanthropyofficerspositions. }\end{array}$ & $\begin{array}{l}\text { 1987: A first law recognizes } \\
\text { philanthropyas a mainstream } \\
\text { corporate practice. It grants } \\
\text { corporations some (limited) } \\
\text { fiscal advantages. } \\
\text { 1990: A new law institutes } \\
\text { "corporate foundations", } \\
\text { relieving statutory obstacles to } \\
\text { philanthropic practices. } \\
\text { Early 90s: corporate } \\
\text { philanthropy opens up to } \\
\text { solidarity as well as } \\
\text { environmental projects (in } \\
\text { addition to culture). } \\
\text { Early 90s: Employee } \\
\text { volunteering practices emerge in } \\
\text { corporations. } \\
\text { Late 90s: practices spread } \\
\text { outside of Paris with the creation } \\
\text { of local corporate philanthropy } \\
\text { clubs. }\end{array}$ & $\begin{array}{l}\text { 2003: A new law grants French } \\
\text { corporations with one of the most } \\
\text { favorable tax exemption system } \\
\text { in the world. } \\
\text { 2007: A new law authorizes the } \\
\text { creation of endowment funds by } \\
\text { individuals as well as } \\
\text { corporations. } \\
\text { 2007: Jacques Rigaud, the father } \\
\text { of corporate philanthropy, steps } \\
\text { down as chair of ADMICAL. } \\
\text { 2008 - 2010: The financial crisis } \\
\text { impacts corporate philanthropy } \\
\text { by shifting resources from culture } \\
\text { to solidarity, but does not } \\
\text { drastically reduce their amount. } \\
\mathbf{2 0 1 0 : ~ I M S ~ p r o d u c e s ~ t h e ~ f i r s t ~} \\
\text { study on the corporate } \\
\text { philanthropy manager profession, } \\
\text { highlighting its core skills and } \\
\text { functions. } \\
\mathbf{2 0 1 1 :} \text { ADMICAL issues the first } \\
\text { "Charter for Corporate } \\
\text { Philanthropy". }\end{array}$ \\
\hline
\end{tabular}




\section{FIGURE 1}

The institutionalization of formal corporate philanthropy policies and officers among large French corporations (1984 - 2012)

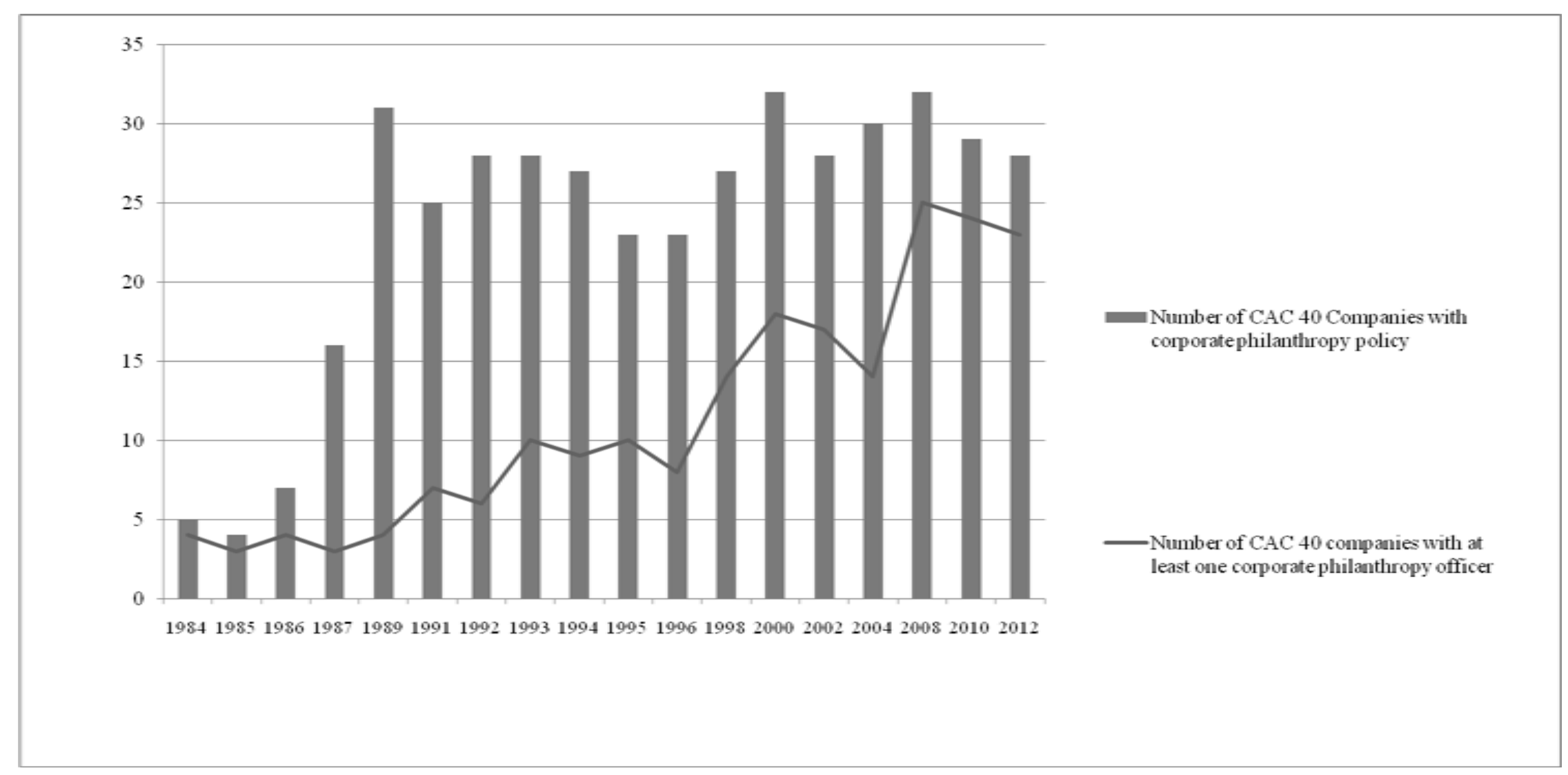

Source: “Repertoire du mecenatd'entreprise", edited by ADMICAL 
TABLE 2

Theorizing corporate philanthropy and corporate philanthropy positions

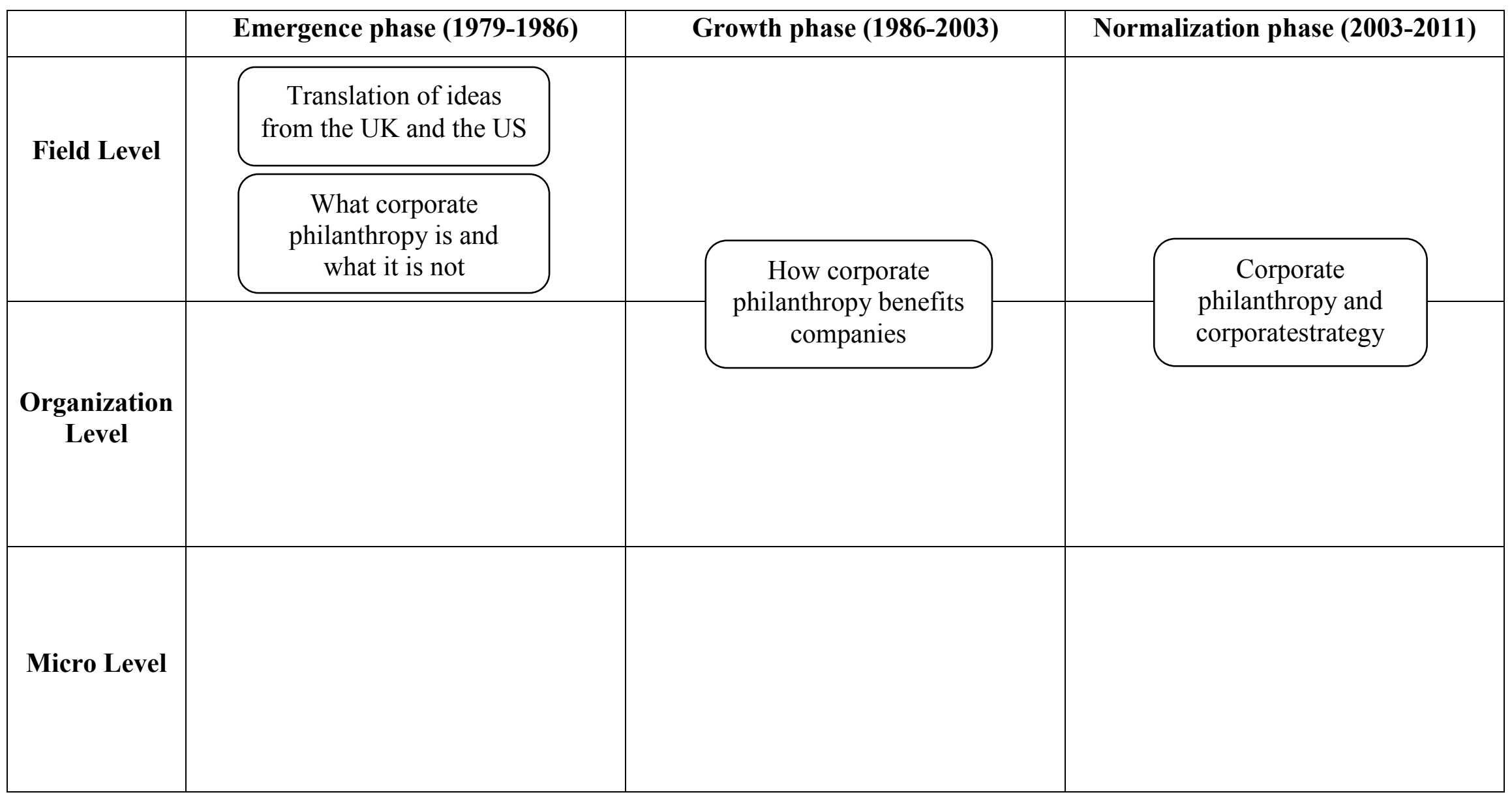




\section{TABLE 3}

Mobilizing resources for corporate philanthropy and corporate philanthropy positions

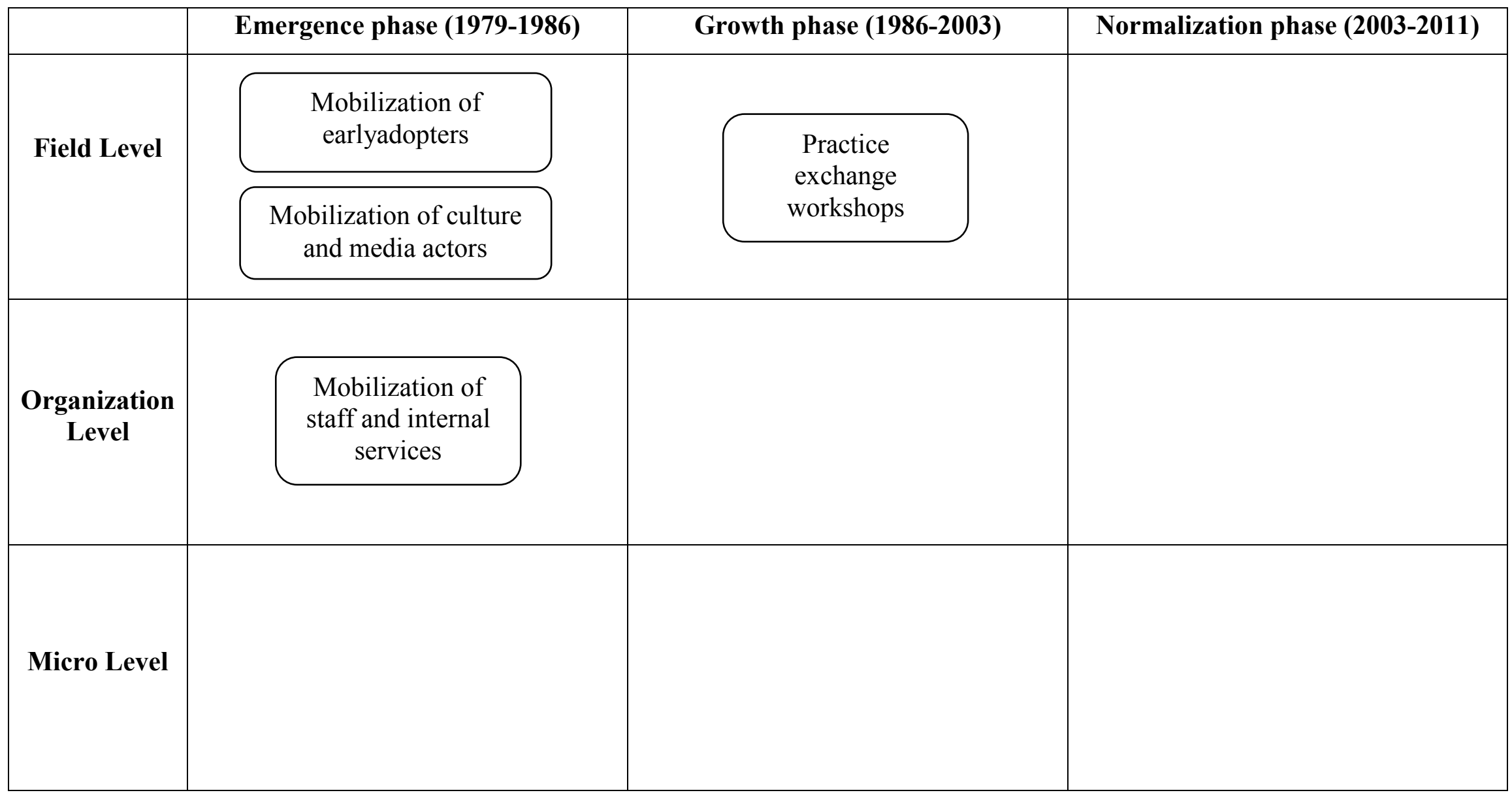


TABLE 4

Institutionalizing corporate philanthropy and corporate philanthropy positions

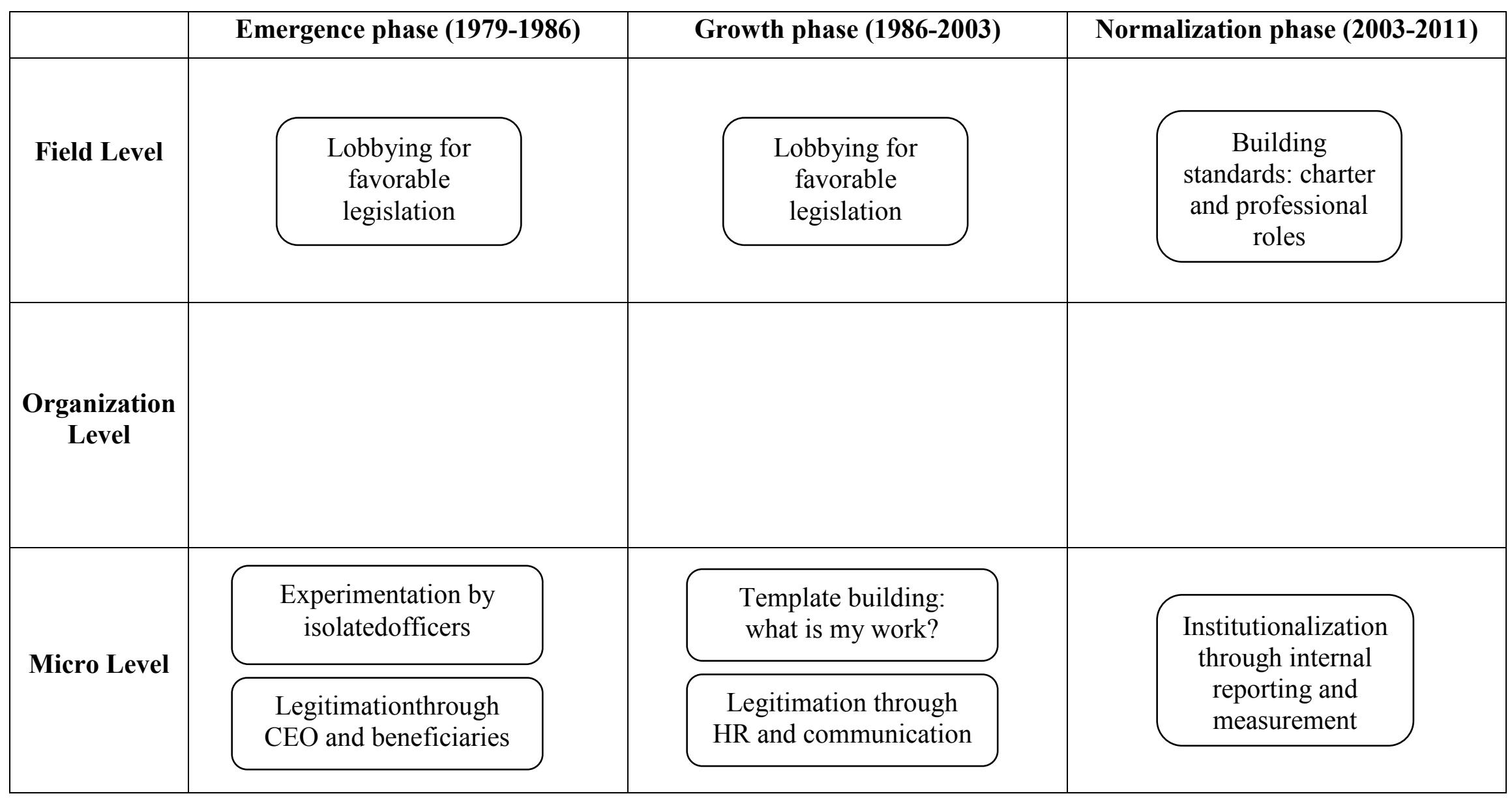


ESSEC Business School Avenue Bernard Hirsch BP 50105

95021 Cergy-Pontoise Cedex France

Tél. +33(0)134433000

$\mathrm{Fax}+33(0) 134433001$

www.essec.fr

\section{ESSEC Executive Education} CNIT BP 230

92053 Paris-La Défense France

Têl. + $33(0) 146924900$

Fax +33 (0)1 46924990

http://formation.essec.fi

ESSEC Business School

Singapore Campus

100 Victoria Street

National Library Building \# 13-02

Singapore 188064

essecasia@essec.fr

Tél. +6568849780

Fax +6568849781

www.essec.edu

Informations

Alison Bougi

+33 (0)134433358

bougi@essec.fr

www.essec.fr

research.center@essec.fr

ISSN 1291-9616 